\title{
INCREASED SALIVARY AND SERUM LEVELS OF IL-33 IN PATIENTS WITH ORAL PEMPHIGUS VULGARIS
}

\author{
Gihane Gharib Madkour* and Ibrahim EL Refaie**
}

\begin{abstract}
Objective: The objective of this study was to investigate salivary and serum levels of IL-33 in oral pemphigus vulgaris patients, before and after corticosteroid therapy, in a trial to elucidate its possible role in the disease pathogenesis.
\end{abstract}

Subjects and Methods: This study included 30 individuals; 15 patients with oral pemphigus vulgaris and 15 healthy controls. Salivary and serum samples were collected from all patients, before and after corticosteroid therapy, and form healthy controls. IL-33 was quantified in all salivary and serum samples utilizing enzyme-linked immunosorbent assay (ELISA).

Results: Compared to healthy controls, IL-33 levels were statistically significantly higher in saliva and serum of patients with oral pemphigus vulgaris. Salivary and serum Levels of IL-33 decreased significantly in all patients after corticosteroid therapy.

Conclusion: Results of this study suggest that IL-33 may have a key role in oral pemphigus vulgaris pathogenesis. IL-33 may become a new therapeutic target for oral pemphigus vulgaris.

KEYWORDS: Oral Pemphigus vulgaris, IL-33, saliva, serum.

\section{INTRODUCTION}

Pemphigus vulgaris (PV) is a severe autoimmune intraepithelial vesiculo-bullous disease affecting skin and/or mucous membranes ${ }^{1}$. Oral lesions of PV are the first early manifestations of the disease in about $70-90 \%$ of the cases and they are the only manifestations in nearly $50 \%$ of the patients ${ }^{2-4}$.

Clinically, oral manifestations are characterized by blisters with very thin and fragile roof that rapidly rupture, resulting in chronic painful erosions with epithelial remnants at its periphery. The most common picture is that of persistent, large and multiple erosions that are covered by yellow exudates and tend to extend progressively by peripheral extension with little tendency to heal ${ }^{5,6}$. Lesions may extend out on the vermillion border of the lips forming heavy hemorrhagic crusts. The Nikolsky sign is positive ${ }^{1,7}$.

* Associate Professor of Oral Medicine, Diagnosis and Periodontology, Faculty of Oral and Dental Medicine, Cairo University, Egypt.

** Lecturer of Oral Medicine, Diagnosis and Periodontology, Faculty of Oral and Dental Medicine, Cairo University, Egypt. 
PV is due to circulating $\operatorname{IgG}$ autoantibodies directed against a normal desmosomal cell adhesion glycoprotein, known as Desmoglein (Dsg), present on the cell membrane of keratinocytes ${ }^{6,8}$. It has been demonstrated that early in the course of the disease, when lesions are limited to mucous membranes, patients have antibodies only against Dsg3. AntiDsg1 antibodies was found later in the progress of PV disease, coinciding with skin involvement ${ }^{1,9}$.

Although the immunopathology of PV is clearly related to autoantibodies, cellular immunity is also involved in the pathogenesis of the disease ${ }^{10,11}$. It has been proven that autoreactive T-cells have a key role in PV pathogenesis ${ }^{12,13}$. Autoreactive T-cells from PV patients produce predominantly Th2 cytokines ${ }^{14}$. Th2 cytokines including IL-6, IL-15 and TNF- alpha ${ }^{15}$, IL-10 ${ }^{10}$ and IL-1alpha and TNF- alpha ${ }^{16}$ are presumably involved in PV pathogenesis ${ }^{1}$.

Several recent studies have focused on the possible role of IL-33, a recently recognized member in the IL-1 family of cytokines ${ }^{17}$, in the pathogenesis of many autoimmune diseases. Precisely, IL-33 has been proven to be involved in the pathogenesis of systemic lupus erythematosus (SLE) ${ }^{18}$, multiple sclerosis (MS) ${ }^{19}$, rheumatoid arthritis (RA) ${ }^{20}$ and Sjogren syndrome (SS) ${ }^{21}$.

IL-33 is expressed by many cells including endothelial cells, fibroblasts, keratinocytes and epithelial cells ${ }^{22}$. Specifically, IL-33 binds to its specific receptor ST2 and subsequently leads to induction of Th2 cytokines gene expression. Nevertheless, IL-33 has been proven to stimulate Th2 immune reactions. Therefore, IL-33 seems to play an important role in autoimmune diseases ${ }^{23}$.

Till date, salivary and serum levels of IL-33 in patients with oral PV have not been assessed. Moreover, possible effects of corticosteroid therapy on the salivary and serum levels of IL-33 have not been investigated. Therefore, this study comparatively investigated salivary and serum levels of IL-33 in patients with oral PV, before and after corticosteroid therapy, and healthy controls.

\section{PATIENTS AND METHODS}

\section{Study Population}

A total of thirty individuals were selected for this randomized controlled clinical study from the outpatient clinic of Oral Medicine, Diagnosis and Periodontology Department, Faculty of Oral and Dental Medicine, Cairo University and the Department of Skin and Venereal diseases, Faculty of Medicine, Cairo University between October 2015 and June 2016. Subjects were divided into two groups as follows:

- Group 1 (Patients group) comprised 15 patients suffering from oral PV (7 males and 8 females). Their ages range from 37 to 52 years with a mean age of 46 years.

- Group 2 (Control group) consisted of 15 systemically healthy subjects (6 males and 9 females). Their ages range from 34 to 49 years with a mean age of 40.5 years.

\section{Inclusion and exclusion criteria}

To be included in the study, all oral PV patients were diagnosed based upon the clinical features and confirmed by histopathological examination of oral biopsy ${ }^{24,25}$. All included subjects did not receive any drug therapy, especially corticosteroids, in the last 6 months. Exclusion criteria included patients with any systemic disease, inflammatory oral lesion or periodontal disease. Smokers were also excluded.

A full medical history for each participating individual was taken according to the detailed questionnaire of the modified Cornell Medical Index ${ }^{26}$. The study protocol was approved by the Institutional Review Board. The procedure of the study as well as giving information about the follow-up appointments needed was explained to all patients. They agreed to participate in the study and signed the appropriate written informed consent form. 
All PV patients were treated with systemic corticosteroids; Prednisolone* 5mg/tab, using the standard dosage of $1 \mathrm{mg} / \mathrm{kg} /$ day with individual variations (60-100 mg/day), depending on disease severity, in a single morning dosage $1 \frac{1}{2}$ hour after arising. The initial therapeutic dose was continued until complete resolution of signs and symptoms of the disease. The dosage was subsequently tapered to a minimum effective maintenance dose ${ }^{27,28}$.

\section{Sample collection}

\section{Saliva sampling:}

Salivary samples were collected in the morning between 9:00 to 10:00 a.m. All participating subjects were fasting from the previous night. Before sample collection, they were requested to rinse their mouth using distilled water. After 5 minutes, whole unstimulated saliva samples were obtained using the simple standard technique by Navazesh ${ }^{29}$. Subjects were told to sit comfortably and to spit into plastic tubes five times per minute for 5 minutes to obtain $5 \mathrm{ml}$ of saliva. All salivary samples were then centrifuged at $4000 \mathrm{xg}$ for 10 minutes at $4{ }^{\circ} \mathrm{C}$, the upper parts were drawn and stored in small aliquots at $-80^{\circ} \mathrm{C}$ until assayed.

Two salivary samples were collected from PV patient's saliva; the first one was taken before starting corticosteroid therapy and the second sample was taken after corticosteroid therapy and complete resolution of signs and symptoms of the disease. Only one sample was taken from the saliva of the control group healthy volunteers on their initial visit.

\section{Serum sampling:}

For all participating subjects, $5 \mathrm{ml}$ of venous blood samples were taken by a standard venipuncture method from the ante-cubital vein and were immediately transferred to the laboratory. Centrifugation was subsequently carried on to separate serum from blood for 10 minutes at $1500 \mathrm{xg}$. All serum samples were then stored at $-70^{\circ} \mathrm{C}$ till further biochemical essay. Two serum samples were taken from PV patients; the first one before starting corticosteroid therapy and the second one after corticosteroid therapy and complete resolution of signs and symptoms of the disease. Only one sample was taken from the control group volunteers.

\section{IL-33 Assay}

Salivary and serum levels of IL-33 of all study participants were assessed by enzymelinked immunosorbent assay (ELISA) (Human IL-33 Quantikine ELISA kit, R\&D systems, Inc. Minneapolis, MN, USA) following manufacturer's instructions. It is sandwich-type ELISA where a monoclonal anti-human IL-33, adsorbed onto micro wells and bind IL-33 in the sample. The intensity of the color was measured at $450 \mathrm{~nm}$. Results were calculated using the standard curve included in the assay kit.

\section{Statistical analysis}

Data were presented as mean and standard deviation (SD) values (mean $\pm \mathrm{SD}$ ). Paired t-test was used to compare between IL-33 levels in serum \& saliva of PV patients before and after treatment. Unpaired Student's t-test was used to compare between IL-33 levels in serum \& saliva of PV patients (before \& after treatment) and control group. Statistical tests were carried out by the GraphPad statistical software (Graph Pad Software Inc, La Jolla, CA). P value $<0.05$ is statistically significant.

\footnotetext{
* Prednisolone 5mg/tab: The Arab Drug Company- Cairo - A.R.E.
} 


\section{RESULTS}

A total of 30 subjects, 15 patients with oral PV and 15 healthy controls were assessed. ELISA was performed to determine salivary and serum levels of IL-33 in patients with oral PV, before \& after corticosteroid therapy, and healthy controls. Salivary and serum mean levels of IL-33 are shown in Table (1) and graphically presented in Figure (1). Our results revealed a statistically significant increased levels of both salivary and serum IL-33 levels in oral PV group, before treatment, compared to control group ( $p<0.0001)$. Furthermore, we found a statistically significant decrease in the mean levels of IL-33 in both saliva and serum of PV patients after corticosteroid therapy $(\mathrm{p}<0.0001)$. In addition, IL-33 mean levels in serum were higher than that in saliva in all the studied groups.

TABLE (1) Analytic Data of mean and standard deviation (SD) of IL-33 levels in saliva and serum of the studied groups

\begin{tabular}{|c|c|c|c|}
\hline \multirow[b]{2}{*}{ Body fluid } & \multicolumn{2}{|c|}{ Group 1 (Oral PV patients) } & \multirow{2}{*}{$\begin{array}{l}\text { Group } 2 \\
\text { (Healthy } \\
\text { Controls) }\end{array}$} \\
\hline & $\begin{array}{c}\text { Before } \\
\text { corticosteroid } \\
\text { therapy }\end{array}$ & $\begin{array}{c}\text { After } \\
\text { corticosteroid } \\
\text { therapy }\end{array}$ & \\
\hline Saliva (pg/ml) & $\begin{array}{l}398.06 \pm \\
108.37 *\end{array}$ & $\begin{array}{l}124.79 \pm \\
63.43 \#\end{array}$ & $\begin{array}{c}58.75 \pm \\
20.24\end{array}$ \\
\hline $\begin{array}{l}\text { Serum }(\mathrm{pg} / \mathrm{ml}) \\
(\text { mean } \pm \mathrm{SD})\end{array}$ & $\begin{array}{l}487.36 \pm \\
129.48 *\end{array}$ & $\begin{array}{l}159.64 \pm \\
49.84 \#\end{array}$ & $\begin{array}{c}79.63 \pm \\
31.46\end{array}$ \\
\hline
\end{tabular}

*Statistically significant difference from the healthy controls (Unpaired Student t-test; $p<0.0001$ ).

\#Statistically significant difference after corticosteroid therapy (Paired t-test; $p<0.001$ ).

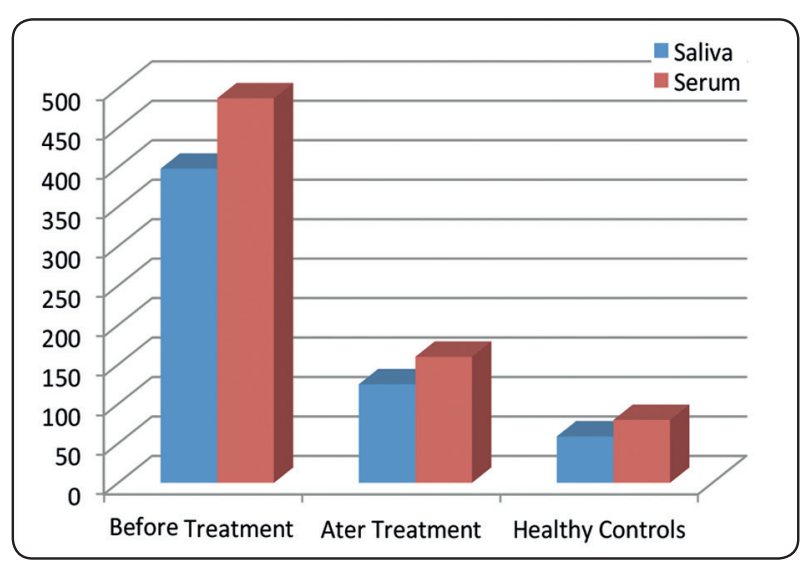

Fig. (1): A histogram representing mean values of salivary and serum levels of IL-33 (pg/ml) in oral PV patients before and after corticosteroid therapy and healthy controls.

\section{DISCUSSION}

Recently, increasing evidence demonstrated that IL-33 plays an important part in the pathogenesis of many autoimmune diseases ${ }^{18-20}$. To our knowledge, this is the first study that investigated IL-33 levels in both saliva and serum of oral PV patients, before and after corticosteroid therapy, in a trial to illustrate its possible role in the disease pathogenesis.

In the current study, levels of IL-33 showed statistically significant increase in both saliva and serum of oral PV patients compared to healthy controls. The results also showed significant decrease in salivary and serum IL-33 levels in oral PV patients after corticosteroid therapy and complete resolution of signs and symptoms of the disease. These results break a new ground for the possible participation of IL-33 in the pathogenic mechanism involved in oral PV and may further contribute to better understand the pathophysiological mechanisms leading to oral PV lesions.

Since we didn't find similar studies in the literature investigating the possible role of IL-33 in oral $\mathrm{PV}$, our results have been compared with results of studies investigating the possible role of IL-33 in other autoimmune diseases. Our results are in agreement with those of Tang et al. ${ }^{20}$ who reported increased IL-33 levels in serum and synovial fluid 
of patients with rheumatoid arthritis. The authors also demonstrated that increased IL-33 levels were correlated with disease activity and autoantibody production. They stated that IL-33 plays a major role in the pathogenic mechanism of rheumatoid arthritis ${ }^{20}$. Moreover, results of this study are consistent with results of Mok et al. ${ }^{18}$ who studied the levels of IL-33 and its soluble ST2 receptor in serum of systemic lupus erythematosus patients. They showed elevated levels of both markers and their association with the disease activity. Furthermore, our results are in accordance with Jung et al. ${ }^{21}$ who revealed elevated levels of IL33 and ST2 receptor in salivary tissues and serum of Sjogren syndrome's patients. They suggested that IL-33 and ST2 receptor may participate in the pathologic process of primary Sjogren syndrome ${ }^{21}$.

Systemic corticosteroids remain the mainstay and gold standard for treatment of PV ${ }^{30,31}$. In our study, systemic oral prednisolone was given to all PV patients to control the disease activity. Prednisolone was chosen because it the preferred corticosteroid for oral systemic administration ${ }^{32}$. A comparison of salivary \& serum levels of IL-33 was performed before and after corticosteroid therapy. Interestingly, we found statistically significant decrease in IL-33 levels in both saliva and serum. These findings additionally assist the possible and relevant participation of IL-33 in oral PV pathogenesis.

IL-33 was recognized in 2005 as the eleventh new member of IL-1 cytokines family ${ }^{17,33}$. Generally, the majority of IL-1 cytokines are proinflammatory cytokines that exert many diverse functions in the innate immune responses. In addition, these cytokines harmonize several local and systemic inflammatory mechanisms. Moreover, they share in acquired immunity through altering naive $\mathrm{T}$ helper lymphocytes differentiation and through direct actions on the diverse functions of $\mathrm{B}$ and $\mathrm{T}$ lymphocytes subsets ${ }^{33}$. Similar to other IL-1 cytokines family members, IL-33 has been proven to be implicated in the regulation of different immune and inflammatory reactions ${ }^{23,33}$.

Schmitz et al. ${ }^{17}$ are the pioneers who demonstrated IL-33 functions and elucidated its diverse biological actions through binding to ST2 receptor ending up with activation of nuclear factor $(\mathrm{NF})-\varkappa \mathrm{B}$ and mitogen activated protein (MAP) kinases. More specifically, the authors clarified that IL-33 induced generation of Th2 cytokines and increased serum immunoglobulin levels. Indeed, B cells have been demonstrated to express ST2 and IL-33 proved to stimulate B cell proliferation and to enhance production of antibodies ${ }^{17,34}$.

It has been emphasized that PV is an autoimmune disease mediated by Th 2 cytokines as demonstrated by many previous investigations. Specifically, autoreactive Th2 cells release cytokines including IL-4, IL-5, IL-10, and IL-13 and apparently promote $\mathrm{IgG}$ autoantibodies production. Indeed, IgG is the autoantibody involved in the pathogenic mechanism of oral PV ${ }^{35-38}$.

Taken together, results of the current study further highlight the potential and crucial role of IL-33 in the pathogenesis of oral PV. More investigations are necessary to elucidate the exact pathophysiological mechanism of IL-33 in oral PV.

\section{CONCLUSION}

Based upon the results of the current study, we concluded that IL-33 may be a potential biomarker for patients with oral PV. Furthermore, IL-33 may be a future hopeful new therapeutic target for treating patients with oral PV.

\section{ACKNOWLEDGMENT}

The authors would like to express sincere appreciation and gratitude to Professor Dr. Nahed Abdel-Moneim Emara, Professor of Clinical Pathology, National Research Center, for her endless efforts and great skillful technical help. 


\section{REFERENCES}

1. Scully C and Challacombe S J (2002) Pemphigus vulgaris: Update on etiopathogenesis, oral manifestations and management. Crit Rev Oral Biol Med 13(5):397-408.

2. Lamey PJ, Rees TD, Binnie WH, Wright JM, Rankin DV, Simpson NB (1992) Oral presentation of pemphigus vulgaris and its response to systemic steroid therapy, Oral Surg Oral Med Oral Pathol; 74: 54-7.

3. Greenberg M S and Glick M (2003) Ulcerative, Vesicular and Bullous lesions, In: Burket's Oral Medicine Diagnosis and treatment, $10^{\text {th }}$ ed. BC Decker, Inc, United States, Pp. 50- 84 .

4. Shamim T, Varghese VI, Shameena PM, Sudha S (2008) Pemphigus vulgaris in oral cavity: clinical analysis of 71 cases. Med Oral Patol Oral Cir Bucal; 13:E622-E626.

5. Murphy G (2003) Blistering (bullous) disease. In: Robbins basic pathology, 7th ed. Eds: Robbins S L, Kumar V and Cotran R S, Pp795-98.

6. Black M, Mignogna MD, Scully C (2005) Number II. Pemphigus vulgaris, Oral Dis 11: 119-130.

7. Gleaves T R, Cather J C and Menter A (2005) Oral erosions and cutaneous bullae. Proc (Bayl Univ Med Cent); 18(1): 71-73.

8. Bascones-Martinez A, Munoz-Corcuera M, BasconesIlundain C, Esparza-Gómez G (2010) Oral Manifestations of Pemphigus Vulgaris: Clinical Presentation, Differential Diagnosis and Management, J Clin Exp Dermatol Res $1: 112$.

9. Ruocco E, Baroni A, Wolf R, Ruocco V (2005) Lifethreatening bullous dermatoses: Pemphigus vulgaris. Clin Dermatol; 23: 223-226.

10. Toto P, Feliciani C, Amerio P, Suzuki H, Wang B, Shivji G, Woodley D and Sauder D (2000) Immune modulation in pemphigus vulgaris: Role of CD28 and IL-10. J.Immunol.; 164: 522-9,.

11. Veldman C, Stauber A, Wassmuth R, Uter W, Schuler G and Hertl M (2003) Dichotomy of autoreactive Th1 and Th2 cell responses to desmoglein 3 in patients with pemphigus vulgaris (PV) and healthy carriers of PV-associated HLA class II alleles. J.Immunol.; 170 (1): 635-42.

12. Rizzo C, Fotino M, Zhang Y, Chow S, Spizuoco A, and Sinha A A (2005) "Direct characterization of human T cells in pemphigus vulgaris reveals elevated autoantigen- specific Th2 activity in association with active disease," Clinical and Experimental Dermatology, 30 (5): 535-540.

13. Satyam A, Khandpur S, Sharma V K, and Sharma A (2009) "Involvement of TH1/TH2 cytokines in the pathogenesis of autoimmune skin disease pemphigus vulgaris," Immunological Investigations; 38(6): 498-509.

14. Hertl M and Riechers R (1999) Analysis of the T cells that are potentially involved in autoantibody production in pemphigus vulgaris, J.Dermatol.; 26 (11): 748- 52.

15. Ameglio F, D'Auria L, Cordiali-Fei P, Trento E, D'Agosto G and Mastroianni A (1999) Anti-intercellular substance antibody $\log$ titres are correlated with serum concentrations of interleukin-6, interleukin-15 and tumor necrosis factoralpha in patients with pemphigus vulgaris relation-ships with peripheral blood neutrophil counts, disease severity and duration and patients' age. J Biol Regul Homeost Agents 13:220-224

16. Feliciani C, Toto P, Amerio P, Pour S M, Coscione G and Shivji G (2000) In vitro and in vivo expression of interleukin-1 alpha and tumor necrosis factor-alpha mRNA in pemphigus vulgaris: interleukin-1alpha and tumor necrosis factor- alpha are involved in acantholysis. J Invest Dermatol 114:71-77.

17. Schmitz J, Owyang A, Oldham E, Song Y, Murphy E, McClanahan TK, Zurawski G, Moshrefi M, Qin J, Li X, et al. (2005) IL-33, an interleukin-1-like cytokine that signals via the IL-1 receptor-related protein ST2 and induces T helper type 2-associated cytokines. Immunity; 23: 479-90.

18. Mok M Y, Huang F P, Ip W K, Lo Y, Wong F Y, Chan E Y T, Lam K F, Xu D (2010) "Serum levels of IL-33 and soluble ST2 and their association with disease activity in systemic lupus erythematosus," Rheumatology; 49 (3): 520-527.

19. Christophi G P, Gruber R C, Panos M, Christophi R L, Jubelt B, and Massa P T (2012) "Interleukin-33 upregulation in peripheral leukocytes and CNS of multiple sclerosis patients," Clinical Immunology; 142 (3) 308319.

20. Tang S, Huang H, Hu F, Zhou W, Guo J, Jiang H, Mu R, Li Z (2013). Increased IL-33 in synovial fluid and paired serum is associated with disease activity and autoantibodies in rheumatoid arthritis. Clin Dev Immunol.; 2013:985301.

21. Jung S M, Lee J, Baek S Y, Lee J H, Lee J, Park K S, Park S H, Kim H Y, Kwok S K (2015) The Interleukin 33/ST2 axis in patients with primary Sjögren syndrome: 
expression in serum and salivary glands, and the clinical association. J Rheumatol.; 42(2):264-71.

22. Moussion C, Ortega N, Girard J P (2008) The IL-1-like cytokine IL-33 is constitutively expressed in the nucleus of endothelial cells and epithelial cells in vivo: a novel ‘alarmin'? PLoS One; 3: e3331.

23. Zhao Q and Chen G (2014) Role of IL-33 and its receptor in $\mathrm{T}$ cell-mediated autoimmune diseases, Biomed Res Int.; 2014: 587376.

24. Scully C, Paes De Almeida O, Porter SR, Gilkes JJ (1999). Pemphigus vulgaris: the manifestations and long-term management of 55 patients with oral lesions. Br J Dermatol 140: 84-89.

25. Mahajan V K, Sharma L, Sharma R C and Garg G (2005) Twelve-year clinico-therapeutic experience in pemphigus: A retrospective study of 54 cases. International Journal of Dermatology; 44 (10): 821-827.

26. Abramson JH (1966) "The Cornell medical index as an epidemiological tool," Am J of Public Health and the Nation's Health; 56(2): 287-298.

27. Fernandes N C and Perez M (2001) Treatment of pemphigus vulgaris and pemphigus foliaceus: experience with 71 patients over a 20 year period. Rev Inst Med Trop Sao Paulo; 43(1):33-6.

28. Harman K E, Albert S, Black M M (2003) Guidelines for the management of pemphigus vulgaris. Br J Dermatol; 149:926-937.

29. Navazesh M (1993) Methods for collecting saliva. Ann NY Acad Sci; 694:72-77.
30. Mignogna M D, Lo Muzio L, Mignogna R E, Carbone R, Ruoppo E, Bucci E (2000) Oral pemphigus: long term behaviour and clinical response to treatment with deflazacort in sixteen cases. J Oral Pathol Med 29:145-152.

31. Daniel B S, Murrell D F (2014) Management of pemphigus. F1000Prime Reports; 6:32.

32. Tóth G G and Jonkman M F (2001) Therapy of pemphigus. Clin Dermatol; 19:761-7.

33. Garlanda C, Dinarello C A and Mantovani A (2013) The interleukin-1 family: back to the future. Immunity 39, 1003-1018.

34. Komai-Koma M, Gilchrist D S, McKenzie A N, Goodyear C S, Xu D and Liew F Y (2011) IL-33 activates B1 cells and exacerbates contact sensitivity. J Immunol; 186 (4), 2584-2591.

35. Eming R, Büdinger L, Riechers R, Christensen O, Bohlen H, Kalish R et al (2000) Frequency analysis of autoreactive T-helper 1 and 2 cells in bullous pemphigoid and pemphigus vulgaris by enzyme-linked immunospot assay. Br J Dermatol; 143:1279-1282.

36. Caproni M, Giomi B, Cardinali C, Salvatore E, Pestelli E, D'Agata A, Bianchi B et al (2001) Further support for a role for Th2-like cytokines in blister formation of pemphigus. Clin Immunol; 98:264-271.

37. Hertl M, Eming R, Veldman C (2006) T cell control in autoimmune bullous skin disorders. J Clin Invest; 116:1159-1166

38. Giordano C N, Sinha A A (2012) Cytokine networks in Pemphigus vulgaris: An integrated viewpoint. Autoimmunity; 45(6):427-39 